\title{
An Association of Rh Type and Gynaecological Disease with Twinning
}

\author{
FRANCES V. DE GEORGE \\ From the Department of Medical Genetics, University of Wisconsin, Madison, Wisconsin, U.S.A.
}

Earlier twin studies (Osborne and De George, 1957) suggested there might be an excess of group $O$ mothers having twins.

The present investigation aims at determining if the $\mathrm{ABO}$ and $\mathrm{Rh}$ blood groups, or history of gynaecological disease are predisposing influences in twining.

\section{Materials and Methods}

The medical record numbers of mothers giving birth to twins were obtained from the obstetric files of the New York Lying-In Hospital of the New York-Cornell medical Center for the period 1955-1964. This source identified all the mothers delivering twins with the birthweights of $500 \mathrm{~g}$. or more. From these files a control was selected of mothers delivering only single-born. Each mother of twins was matched with a mother of a singleton by age, race, hospital service, and with delivery date as close to that of the twin birth as feasible. The medical record of each mother of twins and singleborn control was directly abstracted for the following information: birth dates, ethnic origins, and religions of the mothers and their spouses; mother's menstrual history, medical, surgical, and pregnancy experience, and blood groups (ABO and $\mathrm{Rh}$ ). Data were recorded for all pregnancies on the records.

There were 496 mothers of twins identified: 409

Received September 3, 1968.
Caucasian (323 Gentile and 86 Jewish), 54 Negro, 31 Puerto Rican, and 2 Oriental. Due to the heterogeneity among the different ethnic groups, the data for Jews, Negroes, and Puerto Ricans are combined with the Gentile data only when appropriate to the analysis.

\section{Results}

ABO and Rh Blood Groups. Table I presents the distribution of the $A B O$ and $R h$ blood groups among the twin and control mothers. The ABO distribution does not differ significantly between the mothers of twins and singletons. However, the frequency of $R h$ negative mothers is considerably higher in the Gentiles and Jews of the twin group, $22 \%$ and $15 \%$, compared to their respective controls, $17 \%$ and $7 \%$.

The $\mathrm{Rh}$ frequencies are clearly heterogeneous. This is even more pronounced when the data from Negro and Puerto Rican mothers are included. These data were therefore analysed by matchedpair methods (Worcester, 1964), and the results are given in Table II; these include all twin births for which matched controls were available. There were 82 cases where the twin mother was $R h$ negative and the singleton mother was $R h$ positive, and only 48 where the situation was reversed. The probability of this large a deviation from equality is less than $0 \cdot 005$. This result is highly significant, and is

TABLE I

DISTRIBUTION OF ABO AND Rh BLOOD GROUPS IN MOTHERS OF TWINS AND SINGLETONS

\begin{tabular}{|c|c|c|c|c|c|c|c|c|c|c|c|c|c|}
\hline & & \multicolumn{5}{|c|}{ Mothers of Twins } & \multicolumn{5}{|c|}{ Mothers of Singletons } & \multirow{2}{*}{$\underset{\substack{\left(\frac{2}{3}\right) \\
\mathrm{ABO}}}{\mathrm{ABO}}$} & \multirow{2}{*}{$\begin{array}{r}\mathrm{Rh} \\
\chi \chi_{(1)}^{2}\end{array}$} \\
\hline & & $\mathbf{O}$ & $\mathbf{A}$ & B & $\mathbf{A B}$ & Total & $\mathrm{O}$ & A & B & $\mathbf{A B}$ & Total & & \\
\hline Gentiles & $\begin{array}{l}\mathbf{R h}+ \\
\mathbf{R h}- \\
\text { Total }\end{array}$ & $\begin{array}{r}112 \\
38 \\
150\end{array}$ & $\begin{array}{r}99 \\
25 \\
124\end{array}$ & $\begin{array}{r}30 \\
6 \\
36\end{array}$ & $\begin{array}{r}8 \\
2 \\
10\end{array}$ & $\begin{array}{r}249 \\
71 \\
320\end{array}$ & $\begin{array}{r}121 \\
24 \\
145\end{array}$ & $\begin{array}{r}100 \\
20 \\
120\end{array}$ & $\begin{array}{r}33 \\
4 \\
37\end{array}$ & $\begin{array}{r}10 \\
6 \\
16\end{array}$ & $\begin{array}{r}264 \\
54 \\
318\end{array}$ & 1.56 & $2 \cdot 74$ \\
\hline Jews & $\begin{array}{l}\text { Rh }+ \\
\text { Rh- } \\
\text { Total }\end{array}$ & $\begin{array}{r}25 \\
7 \\
32 \\
\end{array}$ & $\begin{array}{r}25 \\
3 \\
28\end{array}$ & $\begin{array}{c}14 \\
1 \\
15\end{array}$ & $\begin{array}{l}7 \\
2 \\
9\end{array}$ & $\begin{array}{l}71 \\
13 \\
84\end{array}$ & $\begin{array}{r}30 \\
3 \\
33\end{array}$ & $\begin{array}{r}33 \\
2 \\
35\end{array}$ & $\begin{array}{r}9 \\
1 \\
10\end{array}$ & $\begin{array}{l}8 \\
0 \\
8\end{array}$ & $\begin{array}{r}80 \\
6 \\
86\end{array}$ & $1 \cdot 45$ & $3 \cdot 80$ \\
\hline Total & $\begin{array}{l}\mathbf{R h}+ \\
\mathbf{R h}- \\
\text { Total }\end{array}$ & $\begin{array}{r}137 \\
45 \\
182\end{array}$ & $\begin{array}{r}124 \\
28 \\
152\end{array}$ & $\begin{array}{r}44 \\
7 \\
51\end{array}$ & $\begin{array}{r}15 \\
4 \\
19\end{array}$ & $\begin{array}{r}320 \\
84 \\
404\end{array}$ & $\begin{array}{r}151 \\
27 \\
178\end{array}$ & $\begin{array}{r}133 \\
22 \\
155\end{array}$ & $\begin{array}{r}42 \\
5 \\
47\end{array}$ & $\begin{array}{r}18 \\
6 \\
24\end{array}$ & $\begin{array}{r}344 \\
60 \\
404\end{array}$ & & \\
\hline
\end{tabular}


TABLE IIA

DISTRIBUTION OF Rh IN PAIRS OF TWIN AND SINGLETON MOTHERS

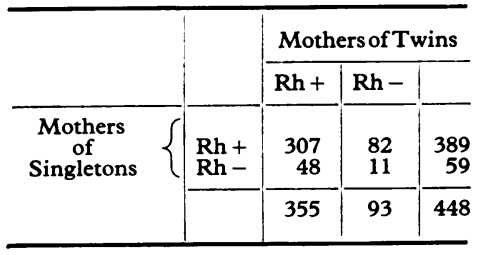

$t=2.98, p=<0.005$.

TABLE IIB

PAIRS WITH BOTH MEMBERS OF

\begin{tabular}{l|l|l|l|l}
\hline & & \multicolumn{3}{|l}{ Mothers of Twins } \\
\cline { 2 - 4 } $\begin{array}{c}\text { Mothers } \\
\text { of } \\
\text { singletons }\end{array}$ & $\mathrm{Rh}+$ & $\mathrm{Rh}-$ & \\
\hline $\mathrm{Rh}+$ & 60 & 20 & 80 \\
$\mathrm{Rh}-$ & 7 & 6 & 13 \\
\hline & 67 & 26 & 93 \\
\hline$t=2.50, \mathrm{p}=>0.01$.
\end{tabular}
BLOOD GROUP O

not affected by the heterogeneity in $\mathrm{Rh}$ frequency in the different ethnic groups, as a conventional chi square would be. Though the numbers are limited, the differences appear to be even more striking in Negro mothers where the $R h$ negative frequency is very low in mothers of singletons.

The inference of an excess of group $O$ women having twins suggested the separate analysis of $\mathrm{Rh}$ in this blood group. This also is shown in Table II, and the difference is still significant: $20 \mathrm{Rh}$ negative twin to $R h$ positive singleton mothers relative to $7 \mathrm{Rh}$ negative singleton to $R h$ positive twin mothers $(p<0.02)$.

Table III gives the distribution of the twin and control mothers by maternal age-groups according to sex of their offspring and the frequency of $R h$ negative mothers. The proportions of $R h$ negative mothers are similar among the age-groups within the twin group, but they are higher than the controls at ages 19-39, especially at ages 35-39. Though the controls are more variable, they do not deviate significantly among the age-groups. The difference in the $R h$ negative frequency between

TABLE III

MATERNAL AGE DISTRIBUTION OF MOTHERS OF TWINS AND SINGLETONS IN RELATION TO SEX OF OFFSPRING, AND Rh NEGATIVE PERCENTAGES (GENTILES)

\begin{tabular}{|c|c|c|c|c|c|c|c|c|c|c|c|c|c|c|c|c|c|c|c|c|c|}
\hline \multirow{4}{*}{$\underset{(y r .)}{\text { Maternal Age }}$} & \multicolumn{12}{|c|}{ Mothers of Twin Pairs } & \multicolumn{9}{|c|}{ Mothers of Singletons } \\
\hline & \multicolumn{3}{|c|}{$\begin{array}{c}\text { Male-Male } \\
\text { Pairs }\end{array}$} & \multicolumn{3}{|c|}{$\begin{array}{c}\text { Female-Female } \\
\text { Pairs }\end{array}$} & \multicolumn{3}{|c|}{$\begin{array}{c}\text { Male-Female } \\
\text { Pairs }\end{array}$} & \multirow{3}{*}{ Totals } & & & \multicolumn{3}{|c|}{ Male } & \multicolumn{3}{|c|}{ Female } & \multirow{3}{*}{ Totals } & & \\
\hline & \multirow{2}{*}{ No. } & \multicolumn{2}{|c|}{ Rh Neg. } & \multirow{2}{*}{ No. } & \multicolumn{2}{|c|}{ Rh Neg. } & \multirow{2}{*}{ No. } & \multicolumn{2}{|c|}{ Rh Neg. } & & \multicolumn{2}{|c|}{ Rh Neg. } & \multirow{2}{*}{ No. } & \multicolumn{2}{|c|}{ Rh Neg. } & \multirow{2}{*}{ No. } & \multicolumn{2}{|c|}{ Rh Neg. } & & \multicolumn{2}{|c|}{ Rh Neg } \\
\hline & & No. & $\%$ & & No. & $\%$ & & No. & $\%$ & & No. & $\%$ & & No. & $o_{0}$ & & No. & $\%$ & & No. & $\%$ \\
\hline $\begin{array}{r}<20 \\
20-24 \\
25-29 \\
30-34 \\
35-39 \\
40-43\end{array}$ & $\left.\begin{array}{r}6 \\
25 \\
31 \\
31 \\
21 \\
6\end{array}\right\}$ & $\begin{array}{l}12 \\
11\end{array}$ & $\begin{array}{l}19 \\
19\end{array}$ & $\left.\begin{array}{r}6 \\
22 \\
31 \\
21 \\
13 \\
3\end{array}\right\}$ & 13 & $\begin{array}{l}22 \\
19\end{array}$ & $\left.\begin{array}{r}1 \\
17 \\
36 \\
33 \\
14 \\
3\end{array}\right\}$ & 17 & $\begin{array}{l}20 \\
34\end{array}$ & $\begin{array}{l}13 \\
64 \\
98 \\
85 \\
48 \\
12\end{array}$ & $\begin{array}{r}3 \\
13 \\
20 \\
21 \\
11 \\
3\end{array}$ & $\begin{array}{l}23 \\
20 \\
20 \\
25 \\
23 \\
25\end{array}$ & $\left.\begin{array}{r}8 \\
35 \\
48 \\
54 \\
29 \\
6\end{array}\right\}$ & 13 & 15 & $\left.\begin{array}{r}5 \\
29 \\
50 \\
29 \\
19 \\
6\end{array}\right\}$ & 12 & 22 & $\begin{array}{l}13 \\
64 \\
98 \\
83 \\
48 \\
12\end{array}$ & $\begin{array}{r}3 \\
9 \\
17 \\
17 \\
5 \\
3\end{array}$ & $\begin{array}{l}23 \\
14 \\
17 \\
20 \\
10 \\
25\end{array}$ \\
\hline Totals & 120 & 23 & 19 & 96 & 20 & 21 & 104 & 28 & 27 & 320 & 71 & 22 & 180 & 30 & 17 & 138 & 24 & 17 & 318 & 54 & 17 \\
\hline
\end{tabular}

TABLE IV

Rh NEGATIVE FREOUENCY IN MOTHERS OF TWINS AND SINGLETONS IN RELATION TO GRAVIDITY AT TIME OF STUDY (CAUCASIANS)

\begin{tabular}{|c|c|c|c|c|c|c|c|}
\hline \multirow{3}{*}{ Gravidity } & \multicolumn{3}{|c|}{$\begin{array}{l}\text { Mothers } \\
\text { of Twins }\end{array}$} & \multicolumn{3}{|c|}{$\begin{array}{c}\text { Mothers } \\
\text { of Singletons }\end{array}$} & \multirow{3}{*}{$\begin{array}{l}\text { Ratio of Rh Neg. } \\
\text { Mothers of } \\
\text { Twins: Singletons }\end{array}$} \\
\hline & \multirow{2}{*}{$\begin{array}{l}\text { Total No. } \\
\text { of } \\
\text { Mothers }\end{array}$} & \multicolumn{2}{|c|}{$\begin{array}{c}\text { Rh } \\
\text { Negative }\end{array}$} & \multirow{2}{*}{$\begin{array}{l}\text { TotalNo. } \\
\text { of } \\
\text { Mothers }\end{array}$} & \multicolumn{2}{|c|}{$\underset{\text { Negative }}{\text { Rh }}$} & \\
\hline & & No. & $\%$ & & No. & $\%$ & \\
\hline $\begin{array}{l}1 \\
2 \\
3 \\
4 \\
5^{+}\end{array}$ & $\begin{array}{r}135 \\
103 \\
81 \\
42 \\
43\end{array}$ & $\begin{array}{l}22 \\
19 \\
22 \\
11 \\
10\end{array}$ & $\begin{array}{l}16 \\
18 \\
27 \\
26 \\
23\end{array}$ & $\begin{array}{r}143 \\
114 \\
65 \\
33 \\
49\end{array}$ & $\begin{array}{r}18 \\
13 \\
13 \\
6 \\
10\end{array}$ & $\begin{array}{l}13 \\
11 \\
20 \\
18 \\
20\end{array}$ & $\begin{array}{l}1.52: 1.00 \\
1.54: 1.00 \\
1.52: 1.00 \\
1.65: 1.00 \\
1.15: 1.00\end{array}$ \\
\hline Totals & 404 & 84 & 21 & 404 & 60 & 15 & $1.51: 1.00$ \\
\hline
\end{tabular}


mothers of like-sexed and unlike-sexed pairs is mainly the consequence of the more marked deviation at maternal ages $30-43$ years, $19 \%$ and $34 \%$, respectively.

The proportions of $\mathrm{Rh}$ negative mothers in relation to their gravidity at the time of study are given in Table IV. The Rh negative frequencies are increased in multigravidae, i.e. gravida 3 and over, in both groups of mothers. It is noteworthy that the number of living children relative to the total number of previous pregnancies is remarkably similar in $\mathrm{Rh}$ positive and $\mathrm{Rh}$ negative mothers of twins, 0.76 and 0.76 , and singletons, 0.80 and 0.76 , respectively. However, according to the data available on previous pregnancies, there were more $\mathrm{Rh}$ positive than $\mathrm{Rh}$ negative offspring to twin (43:23) compared to control $(20: 18) \mathrm{Rh}$ negative mothers. There are consistently higher $\mathrm{Rh}$ negative frequencies in mothers of twins, as indicated by the ratios (Table IV). The increased frequencies observed in multigravidae apply to mothers of likesexed as well as unlike-sexed pairs, approximately $26 \%$ for each. In mothers of unlike-sexed pairs who also were ages $30-43$ years, $39 \%$ are $\mathrm{Rh}$ negative.

Both maternal age and parity are associated primarily with dizygotic twinning. Determination of zygosity of individual twin pairs was not possible, but the sexes of the twins were recorded and are given in Table III. The $\mathrm{Rh}$ negative frequency is highest in the mothers of unlike-sexed twins, and of course this group is entirely dizygotic. The frequency in the mothers of like-sexed pairs is intermediate between those in mothers of unlike-sexed twins and singletons, as expected, since the likesexed pairs are a mixture of monozygous and dizygous twins.

From the sex ratio of the twins the proportion of monozygous pairs can be computed to be $35 \%$. Using this, and the Rh negative frequencies in the mothers of unlike-sexed pairs and singletons, and assuming that monozygous twins are like singletons in this regard, the predicted frequencies of $\mathrm{Rh}$ negative mothers would be $21.8 \%$ in male:male pairs and $22.5 \%$ in female : female pairs; these are in good agreement with the observed values, $19 \cdot 2 \%$ and $20 \cdot 8 \%$, respectively.

These findings indicate that the $\mathrm{Rh}$ negative blood group in the mother is associated with twinning, and this is mainly, and probably entirely, with dizygous twinning.

\section{Gynaecological Diseases}

Information was obtained from the hospital records regarding the history of gynaecological diseases in the mothers of twins and their matched controls. In view of the heterogeneity that may exist among the various gynaecological conditions, only data for ovarian cysts and myoma uteri have been analysed, and will be referred to collectively as gynaecological disease(s) in this report. The only positive histories accepted were those in which the mothers had required operation for ovarian cyst or uterine myoma, or when either condition was well described on repeated examination in non-pregnant mothers, and usually symptoms attributed to the condition were present. These criteria were uniformly applied to mothers of the study and control groups. The following analysis includes only those gynaecological diseases experienced before the twin and single-born pregnancies of this study.

Twice as many mothers of the twin group relative to the controls experienced ovarian cysts, $5 \%$ and $2 \%$. Among the 29 pairs discordant for ovarian cysts, in 21 pairs the mothers of twins, and in 8 pairs the mothers of singletons were the members with positive histories. The excess of pairs with mothers of twins affected is statistically significant $(t=2.41 ; p<0.02)$. The findings for uterine myoma are similar; these occurred in $3.7 \%$ and $1.2 \%$ of the study and control mothers, respectively. The greater number of pairs in which only mothers of twins were affected (15) is significant when compared to pairs with only control mothers affected (5) $(t=2 \cdot 24, p=0.025)$.

The proportions of mothers with either ovarian cysts or myoma uteri are given in Table V. The increase in gynaecological disease with advancing age is anticipated, but the greater proportions of mothers of twins with positive histories is obvious at all ages. There were 33 and 12 pairs where only twin and singleton mothers (Table V), respectively, had either disease $(p<0.005)$.

TABLE V

MOTHERS WITH POSITIVE HISTORIES OF GYNAECOLOGICAL DISEASE PRECEDING STUDY PREGNANCY

\begin{tabular}{|c|c|c|c|c|c|}
\hline \multirow[t]{2}{*}{$\begin{array}{c}\text { Mothers' } \\
\text { Ages at } \\
\text { Time of } \\
\text { Study } \\
\text { (yr.) }\end{array}$} & \multirow[t]{2}{*}{$\begin{array}{l}\text { No. of } \\
\text { Mothers }\end{array}$} & \multicolumn{2}{|c|}{$\begin{array}{l}\text { Mothers } \\
\text { of Twins }\end{array}$} & \multicolumn{2}{|c|}{$\begin{array}{l}\text { Mothers } \\
\text { of } \\
\text { Singletons }\end{array}$} \\
\hline & & No. & $\%$ & No. & $\%$ \\
\hline $\begin{array}{r}<20 \\
20-24 \\
25-29 \\
30-34 \\
35-39 \\
40-43\end{array}$ & $\begin{array}{r}13 \\
89 \\
132 \\
107 \\
55 \\
13\end{array}$ & $\begin{array}{r}0 \\
4 \\
7 \\
11 \\
8 \\
4\end{array}$ & $\begin{array}{r}- \\
4 \\
5 \\
10 \\
15 \\
31\end{array}$ & $\begin{array}{l}0 \\
1 \\
3 \\
5 \\
3 \\
2\end{array}$ & $\begin{array}{r}- \\
1 \\
2 \\
5 \\
5 \\
15\end{array}$ \\
\hline Totals & 409 & 34 & 8 & 14 & 3 \\
\hline
\end{tabular}


TABLE VI

DISTRIBUTION OF GYNAECOLOGICAL DISEASE HISTORIES IN PAIRS OF TWIN AND SINGLETON MOTHERS

\begin{tabular}{|c|c|c|c|c|}
\hline & & \multicolumn{3}{|c|}{$\begin{array}{l}\text { Mothers of Twins: } \\
\text { Gynaecological Disease } \\
\text { Histories }\end{array}$} \\
\hline & & Positive & Negative & Total \\
\hline \multirow[t]{2}{*}{$\begin{array}{l}\text { Mothers } \\
\text { of } \\
\text { singletons }\end{array}$} & 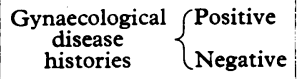 & $\begin{array}{r}2 \\
33\end{array}$ & $\begin{array}{r}12 \\
401\end{array}$ & $\begin{array}{r}14 \\
434\end{array}$ \\
\hline & & 35 & 413 & 448 \\
\hline
\end{tabular}

$t=3 \cdot 13, p<0.005$.

\section{Discussion}

Osborne and De George (1957) suggested that twinning might be more frequent in group $O$ women, at least dizygous twinning (De George and Osborne, unpublished). Previous studies of the ABO blood groups in mothers of twins were on restricted samples: disputed paternity cases (Socha, 1964), and only mothers necessitating hospital deliveries (Wei and Lin, 1967). Hence, their results are not meaningful to this report. The Rh type in mothers of twins was indirectly referred to by Renkonen and Timonen (1967) when they noted the twin incidence was higher in Rh sensitized mothers. They concluded that this finding might be due to the vulnerability of twins to immunological factors, and the greater tolerance of their mothers. In the present study, the $\mathrm{ABO}$ distributions in mothers of twins and singletons are comparable. However, significantly more mothers of twins than of controls were found to be $\mathrm{Rh}$ negative, and this excess also was particularly prominent in blood group $\mathrm{O}$.

There was a statistically significant increased number of ovarian cysts and uterine myoma preceding the twin, compared to the singleton conceptions in this study. Hormonal dysfunction is known to be an aetiological factor in the development of ovarian cysts and uterine myoma. Hormonal substances have been found in the fluid of ovarian cysts (Novak and Woodruff, 1962), and ovarian cysts have been produced experimentally by administration of gonadotrophins (White and Bradbury, 1965; Buxton and Herrmann, 1961). Theca lutein cysts may contain chorionic gonadotrophin, and usually are associated with hydatidiform mole; their occurrence in other pregnancies is considered rare. Among 17 reported cases (Girouard, Barclay, and Collins, 1964), there were 5 with multiple pregnancies, and 6 with severely $R h$ sensitized singletons. Excessive trophoblastic activity has been observed in placentae of pregnancies accompanied by abnormal gonadotrophin excretion. Abnormally high chorionic gonadotrophin levels are found not only in hydatidiform mole and twin pregnancies, but also in $\mathrm{Rh}$ sensitized mothers (Bradbury and Goplerud, 1963; Jeffcoate and Scott, 1959).

In this study an increase in $\mathrm{Rh}$ negative frequency is apparent in multigravidae having twins at both younger and older maternal ages. This suggests that conditions in previous pregnancies may influence subsequent fertility. According to the data available, more $\mathrm{Rh}$ incompatible pregnancies were experienced by mothers of twins than of the controls. These results, and the foregoing reports, imply that the effects of maternofoetal reactions in $\mathrm{Rh}$ incompatible pregnancies are a likely source of subsequent maternal hormonal alterations. In some instances these hormonal alterations may be evidenced by ovarian cysts or myoma uteri, and/or increased fertility due to greater availability of fertilizable ova, or more favourable tubal and uterine environments. An excess of mothers $\mathrm{Rh}$ negative, and mothers with positive histories for gynaecological disease preceding twin conceptions, was observed in the present study. The effects of gynaecological diseases, and of previous pregnancies in $\mathrm{Rh}$ negative mothers appear to influence ovulation. This is inferred from the high proportion of dizygous twin pairs from these mothers.

Twinning has been noted in relation to developmental abnormalities associated with chromosomal aberrations. For example, reports indicate twinning frequency is increased in sibships of patients with Turner's syndrome (Nance and Uchida, 1964). There are also twins affected with this syndrome (Shine and Corney, 1966). The findings of this study are noteworthy, since there may be maternal factors common to twinning and the occurrence of chromosomal aberrations. It would be interesting to know if twins are more frequent than expected among patients with abnormal chromosomal complements, or among their parents. Such evaluations cannot be made from existing reports.

\section{Summary}

The results of this study indicate that $\mathrm{Rh}$ negative blood group and a history of ovarian cysts or uterine myoma are maternal factors predisposing to twinning. An excess of $\mathrm{Rh}$ negative is especially great in twin-producing mothers of blood group $\mathrm{O}$, but the distribution of the $\mathrm{ABO}$ groups per se was not found to differ between mothers of twins and mothers of singletons. The frequencies of $R h$ negative were increased in multigravidae having twins and singletons, though they were consistently higher in mothers of twins, and especially of those 
of unlike-sexed pairs. It is concluded that gynaecological disease, and, materno-foetal reactions in $\mathrm{Rh}$ negative women, may influence subsequent reproductive performance, particularly multiple ovulation leading to dizygous twinning.

I am grateful to Professor James F. Crow, Dept. of Medical Genetics, University of Wisconsin, for advice and help and the opportunity to analyse these data ; to Dr. Gloria E. Sarto, Dept. of Obstetrics and Gynecology, University of Wisconsin, for reading the manuscript; to Dr. R. Gordon Douglas, Chief of the Department of Obstetrics and Gynecology (1964), New York-Cornell Medical Center, for permission to collect these data; and to Miss Frances MacDonald, for access to the department files.

This is paper No. 1268 from the Laboratory of Genetics, University of Wisconsin. As Research Associate in the Division of Human Genetics, Department of Pediatrics, Cornell University Medical College, the collection of these data was supported in part by the National Institutes of Health (HD 00635).

\section{REFERENCES}

Bradbury, J. T., and Goplerud, C. P. (1963). Serum chorionic gonadotrophin studies in sensitized Rh-negative patients. Obstet. and Gy'nec., 21, 330.
Buxton, C. L., and Herrmann, W'. (1961). Induction of ovulation in the human with human gonadotrophins. Preliminary report. Amer. F. Obstet. Gynec., 81, 584.

Girouard, D. P., Barclay, D. L., and Collins, C. G. (1964). Hyperreactio luteinalis. Review of the literature and report of 2 cases. Obstet. and Gynec., 23, 513.

Jeffcoate, T. N. A., and Scott, J. S. (1959). Some observations on the placental factor in pregnancy toxemia. Amer. $\mathcal{F}$. Obstet. Gynec., 77, 475.

Nance, W. E., and Uchida, I. (1964). Turner's syndrome, twinning and an unusual variant of glucose-6-phosphate dehydrogenase. Amer. F. hum. Genet., 16, 380.

Novak, E. R., and Woodruff, J. D. (1962). (Editors.) Gynecologic and Obstetric Pathology, with Clinical and Endocrine Relations, 5th ed. W. B. Saunders, Philadelphia.

Osborne, R. H., and De George, F. V. (1957). Selective survival in dizygotic twins in relation to the $\mathrm{ABO}$ blood groups. Amer. $\mathcal{F}$. hum. Genet., 9, 321.

Renkonen, K. O., and Timonen, S. (1967). Factors influencing the immunization of Rh-negative mothers. f. med. Genet., 4, 166.

Shine, I. B., and Corney, G. (1966). Turner's syndrome in monozygotic twins. ibid., 3, 124.

Socha, W. (1964). Les jumeaux et les groupes sanguins ABO. Folia biol. (Krakow), 12, 83.

Wei, P. Y., and Lin, C. C. (1967). Incidence of twin births among the Chinese in Taiwan. Amer. F. Obstet. Gynec., $98,881$.

White, C. A., and Bradbury, J. T. (1965). Ovarian theca lutein cysts. Experimental formation in women prior to repeat cesarean section. ibid., 92, 973.

W'orcester, J. (1964). Matched samples in epidemiological studies. Biometrics, 20, 840. 